\title{
Performance of Different Hybrids of Watermelon (Citrullus lanatus) under Prayagraj Agro-climatic Condition
}

\author{
Liya Joy*, Vijay Bahadur and Anita Kerketta
}

Department of Horticulture, Naini School of Agriculture, Sam Higginbottom University of Agriculture, Technology and Sciences, Prayagraj 211007 (UP), India

*Corresponding author

\begin{abstract}
A B S T R A C T
An experiment entitled Performance of Different Hybrids of Watermelon (Citrullus lanatus) under Prayagraj Agro-climatic Condition, conducted with twelve Watermelon hybrids was evaluated at SHUATS, Prayagraj in randomized block design with three replications during summer season 2019 for growth, yield and fruit quality traits of Watermelon. Early germination was observed in hybrid F1 Sartaj-295 followed by Hemavathi recorded 6.33 and 7.33 days respectively. The maximum vine length $(\mathrm{cm})$ measured at 30, 60, and 90 DAS was found in variety F1 Sartaj -295 followed by F1 Ajay with $(123.21,238.92,353.83)$ and $(73.91,148.78,338.12)$ respectively. The maximum number of male and female flower per plant was also found in F1 Sartaj-295 with (50.91) and (8.55) respectively. F1 Sartaj-295 was found to be the best variety for fruit length, girth, and weight with $34.87 \mathrm{~cm}, 47.68 \mathrm{~cm}$, and $2.05 \mathrm{gm}$ respectively. The highest fruit yield per plant $(\mathrm{kg})$ and average yield per hectare (Q) was also found in F1 Sartaj-295 (27.23 and 1815.42) followed by Sweet star (22.38 and 1492.04). The quality for colour and appearance, texture, flavor and taste and overall acceptability score was recorded in F1 Sartaj-295 (8.00, 8.67, 8.00 and 8.22). The highest TSS (Brix ${ }^{0}$ ) (15.10) was recorded in F1 Sartaj-295. The economics: gross return (1089252 Rs/ha), net return (918090.4 Rs/ha) and Benefit Cost ratio (6.36) was recorded maximum for F1 Sartaj-295. Thus, F1 Sartaj-295 of watermelon performed best in terms of growth, yield, and quality parameters under the Prayagraj Agro-climate condition.
\end{abstract}

Keywords

Evaluation, Growth, Quality,

Watermelon, Yield

Article Info

Accepted:

04 November 2020

Available Online:

10 December 2020

\section{Introduction}

Vegetables are rich and comparatively cheaper source of vitamins and minerals. Consumption of vegetables provides taste, palatability, increases appetite, and provides fiber for digestion and prevents constipation. They also play a key role in neutralizing the acids produced during digestion of pretentious and fatty foods and also provide valuable roughages that help in the movement of food in the intestine. Cucurbits are vegetable crops belonging to gourd family Cucurbitaceae. Cucurbits share about $5.6 \%$ of the total vegetable production of India and according to FAO estimate, cucurbits were cultivated on about 4,290,000 ha with the productivity of $10.52 \mathrm{t} / \mathrm{ha}$. 
Watermelon (Citrullus lanatus, $2 n=22$ ) is an annual herbaceous, monoecious fruit vegetable that belongs to the family Cucurbitaceae, originated in subtropical Africa. It is now widely cultivated in favorable climates from tropical to temperate regions worldwide having more than 1000 varieties.

Watermelon is a vine-like (scrambler and trailer) flowering plant. It has a large edible fruit, which is a berry with a hard rind and no internal divisions, and is botanically called as "pepo". It is cultivated largely for its fruit which is commonly consumed as juice or as an ingredient in mixed beverages. The sweet, juicy flesh is usually deep red to pink, with many black seeds. The fruit can also be eaten raw or pickled, and the rind is edible after cooking.

A temperature ranging from $25^{\circ} \mathrm{C}$ to $30^{\circ} \mathrm{C}$ is ideal for growth and $25^{\circ} \mathrm{C}$ is the best temperature for the fruit setting of watermelon. The environment significantly influences the flavor and sweetness of the watermelon. The fruit has high nutritive value and is generally low in energy, fat, and sodium and has many medicinal properties. It is often fed to people with a kidney disorders. Watermelon juice is used as an antiseptic in typhus fever. The presence of a fair amount of beta carotene and high content of potassium is believed to make watermelon juice to have valuable diuretic properties.

According to the USDA nutrient database, $100 \mathrm{~g}$ of watermelon contains the following values: $30 \mathrm{kcal}, 7.5 \mathrm{~g}$ Carbohydrate (3\% RDI), $0.4 \mathrm{~g}$ Fiber (2\% RDI), 0.2g Fat (net), $0.6 \mathrm{~g}$ Protein, 569IU Vitamin $A^{*}(11 \%$ RDI), $8.1 \mathrm{mg}$ Vitamin C (13\%RDI), Thiamin (2\% RDI), Vitamin B6 (2\% RDI), Pantothenic Acid (2\% RDI), 10mg Magnesium (2\%RDI), $112 \mathrm{mg}$ Potassium (3\% RDI), Copper (2\% RDI), Manganese (2\% RDI).
India grows approximately 25 commercial varieties; a few of them are Sugar Baby, Vandana, Kiran, Watermelon Sultan, Improved Shipper, Madhubala, Arjun, and Black Magic. Some hybrid watermelons are developed through parthanocarpy which are seedless in nature. Few are as follows; Crimson, Bijou, Jack of Hearts, King of Hearts, Millionaire, Queen of Hearts. Yellow fleshed watermelon varieties are also developed: Yellow crimson, Desert king, Yellow doll. The Yellow and dark red fleshed varieties developed in India are Durgapur Kesar and Durgapur Lal (RARI, Rajasthan) respectively.

Watermelon is rich in vitamin $\mathrm{B}_{6}$ and vitamin $\mathrm{C}$ as well as low in sugar and calories because of a high percentage of water in the fruits, which are useful for those who want to, reduce body weight. It also contains high potassium and low sodium. The antioxidants in watermelons help reduce the risk of heart attack Choudhury (2000). Environmental conditions during production such as light intensity, temperature and irrigation can alter lycopene content by 10-20\% (Perkins-Veazie et al., 2001; Leskovar et al., 2004). Several biochemicals, physiological and structural modifications take place during ripening (Dragovic-Uzelac et al., 2007) resulting in change of color, texture, flavor and aroma (Chisari et al., 2010).

The trend of climate change is already evident; it is likely that these changes will continue. It is the increasing threat of what potential impacts climate change may bring that makes the issue of addressing agricultural adaptation more serious. Diversification is just one aspect of adaptability that is being focused on. Introducing new varieties of watermelons will aid in creating diversification and providing choices to the consumer. 
The improved performance of plants can be manifested in higher yields, tolerance to stresses and increased nutritional value of fruits. This research was therefore aimed at evaluating new varieties of watermelon in Prayagraj region. It provides a simple way to combat climate change by crop diversification.

\section{Materials and Methods}

The research "Performance of different hybrids of watermelon (Citrullus lanatus) under Prayagraj agro-climatic condition" was conducted in the Department of Horticulture, SHUATS, Prayagraj during Kharif season 2019-20 on sandy loam soil type. The experiment was done using a complete randomized block design with twelve hybrids in three replication having $1.5 \times 1 \mathrm{~m}^{2}$ plot size. Hybrids were as follows: $\mathrm{V}_{1}$ : F1Hy black king (Sagar Bio-tech Pvt Ltd., Surat), $\mathrm{V}_{2}$ : F1Hy Mithun (Somani Kanak Seed Pvt Ltd., Haryana), V $\mathrm{V}_{3}$ : F1 Sartaj-295 (Sulabh Seeds Pvt Ltd., Delhi), $\mathrm{V}_{4}$ : Sweet Star (Agriplex Pvt Ltd., Bangalore), $\mathrm{V}_{5}$ : F1 Somya (Ganapathi Seeds Pvt Ltd., Lucknow), V6: F1 Ajay (Laher seeds Pvt Ltd., Ahmedabad), $\mathrm{V}_{7}$ : Goody ball-6 (Noble Seeds Pvt Ltd., Haryana), $\mathrm{V}_{8}$ : Zebra-9 (Implexians Eco solutions Pvt Ltd., Bangalore), $\mathrm{V}_{9}$ : Emerald180 (Rich Grow Seeds pvt Ltd., Delhi), V 10 : Black wonder (RJ Bio-tech Ltd., Aurangabad), Maharastra), $\mathrm{V}_{11}$ : Hemavathi (Hemavathi Agro Farm, Karnataka), V 12 : Sugar baby (Maharastra Hybrid Seeds Company Pvt Ltd.

The land preparation was done including ploughing and leveling of the field and general agronomic practices were done throughout the duration of the research. Fruits were harvested at full maturity by checking the maturity indices. The data collected was analyzed statistically using ANOVA and compared the means of the growth, yield and quality parameters for the watermelon hybrids. This research was therefore aimed at evaluating new hybrids of watermelon under Prayagraj agro-climatic condition.

\section{Results and Discussion}

The analysis of variance indicated significant differences for all the characters indicating variation in the materials.

\section{Growth characteristics}

The minimum days taken for germination of 1st Seedling (6.33 days) were found in F1 Sartaj-295 followed by Hemavathi (7.33). The maximum Days taken for germination of $1 \mathrm{st}$ Seedling (14.67) were observed in hybrid Black Wonder.

The maximum vine length $(\mathrm{cm})$ at 30, 60 and 90 DAS was found in hybrid F1 Sartaj-295 (123.21, 238.92 and 353.83). The minimum vine length $(50.19,112.23$ and 282.18) at 30 , 60 and 90 DAS was recorded in hybrid Black Wonder. The variation in vine length at various hybrids of watermelon may be due to the effect of different genotypes, vigour and environmental condition. These findings confirm with the results of Ahmed et al., (2004) in cucumber, Eifediyi et al., (2009) in cucumber, Ganiger et al., (2014), Manu (2014) and Shruti et al., (2015) in oriental pickling melon (Fig. 1 and Table 1).

The results indicated for the maximum number of primary branches per plant at 30 , 60 and 90 DAS was found in hybrid F1 Sartaj-295 (4.33, 11.33 and 15.33. The minimum number of primary branches per plant $(1.00,4.00$ and 6.00) at 30, 60 and 90 DAS was recorded in hybrid Black Wonder. The maximum number of leaves per plant (64.33, 125.52 and 168.47) at 30, 60 and 90 DAS was found in hybrid F1 Sartaj-295 and the minimum number of leaves per plant 
(25.00, 74.25 and 118.26) at 30, 60, and 90 DAS was recorded in hybrid Black Wonder. The variation in number of leaves and number of primary branches per plant at various hybrids of watermelon may be due to the effect of different genotypes and environmental condition. These findings confirm with the results of Ahmed et al., (2004) in cucumber, Eifediyi et al., (2009) in cucumber, Ganiger et al., (2014), Manu (2014) and Shruti et al., (2015) in oriental pickling melon.

The minimum number of days to first female flower appearance (22.48 days) was found in F1 Sartaj-295 followed by Hemavathi (24.33) and the maximum number of days to first female flower appearance (34.33) was observed in hybrid Black Wonder. The variation in number of days to first female flower appearance may be due to internodal length, number of internodes, genetic factor, environmental factor hormonal factor and vigour of the crop. Similar findings were reported by Sharma and Bhattarai (2016) and Patel et al., (2013).

The maximum number of female flower per plant (8.55) was found in F1 Sartaj 295 followed by Zebra-9 (7.47). The minimum number of female flowers per plant (4.02) was observed in hybrid Black Wonder. Reddy et al., (2012) reported similar results in muskmelon, Yogesh et al., (2009) in cucumber. The maximum number of male flower per plant (50.91) was found in F1 Sartaj-295 followed by Sugar Baby (35.18); F1 Ajay (34.53) and the minimum number of male flowers per plant (19.44) were observed in hybrid Black Wonder..

The variation in maximum number of male and female flower might have been due to intermodal length, number of internodes, genetic factor, environmental factor, hormonal factor and vigour of the crop.
Reddy et al., (2012) reported similar results in muskmelon, Yogesh et al., (2009) in cucumber.

The minimum number of days to first picking (78.67 days) was found in F1 Sartaj-295 followed by Emerald-180 (79) and the maximum number of days to first picking (85.67) was observed in hybrid Black Wonder. The node at which first staminate and pistillate flower appeared is an indication of early flowering which results in getting an early crop. Reddy et al., (2012) reported similar results in muskmelon, Yogesh et al., (2009) in cucumber.

The highest fruit length $(\mathrm{cm})$, width $(\mathrm{cm})$, weight $(\mathrm{kg})$ was found in F1 Sartaj-295 $(34.87 \mathrm{~cm}, 47.68 \mathrm{~cm}$, and $2.05 \mathrm{gm})$ respectively and the lowest fruit length $(\mathrm{cm})$, width $(\mathrm{cm})$, weight $(\mathrm{kg})$ was found in Black Wonder $(21.32 \mathrm{~cm}, \quad 39.95 \mathrm{~cm}, \quad$ and $1.34 \mathrm{gm})$ respectively. These results indicated that higher the growth attributes significantly influenced better translocation of photosynthates from source to sinks resulting in higher yield in such genotypes. Similar observations were made by Vijayakumari et al., (2005) in cucumber, Babu (2013), Ganiger et al., (2014), Manu (2014) and Shruti et al., (2015) in oriental pickling melon.

\section{Yield characteristics}

The highest number of fruit per plant (12.83) was found in F1 Sartaj-295 followed by Sweet Star (10.94) and Zebra-9 (9.62). The variation in number of fruits per vine may be due to sex ratio, fruit set percentage genetic nature and their response to varying environmental conditions. The highest fruit yield per plant $(\mathrm{kg})$ and average yield per hectare (Q) was found in F1 Sartaj-295 (27.23 and 1815.42) followed by Sweet star (22.38 and 1492.04). The significant variation in 
yield per plant may be due to the fruit set percentage, number of fruit per plant, fruit length, fruit diameter and fruit weight. Similar observations were made by Vijayakumari et al., (2005) in cucumber, Babu (2013), Ganiger et al., (2014), Manu (2014) and Shruti et al., (2015) in oriental pickling melon (Fig. 2 and Table 2).

Table.1 Evaluation of watermelon hybrids on Growth parameters

\begin{tabular}{|l|c|c|c|c|c|}
\hline Hybrids & $\begin{array}{c}\text { Days to } \\
\text { germination }\end{array}$ & $\begin{array}{c}\text { Vine length } \\
\text { (cm) }\end{array}$ & $\begin{array}{c}\text { No: of } \\
\text { primary } \\
\text { branches/ } \\
\text { plant }\end{array}$ & $\begin{array}{c}\text { Days to female No: of female } \\
\text { flower }\end{array}$ & No: of male \\
flowers/plant flowers/plant
\end{tabular}

Table.2 Evaluation of watermelon hybrids on Yield parameters

\begin{tabular}{|l|c|c|c|c|c|}
\hline Hybrids & $\begin{array}{c}\text { Fruit Length } \\
(\mathbf{c m})\end{array}$ & $\begin{array}{c}\text { Fruit } \\
\text { Width } \\
\text { (cm) }\end{array}$ & $\begin{array}{c}\text { Fruit Weight } \\
\text { (Kg) }\end{array}$ & $\begin{array}{c}\text { Fruit } \\
\text { Yield/Plant }\end{array}$ & $\begin{array}{c}\text { Average } \\
\text { Yield/ha } \\
(\mathbf{Q})\end{array}$ \\
\hline F1 Black king & 24.4 & 43.86 & 1.77 & 13.67 & 911.48 \\
\hline F1 Mithun & 27.53 & 42.28 & 1.82 & 12.49 & 832.76 \\
\hline F1 Sartaj-295 & 34.87 & 47.68 & 2.12 & 27.23 & 1815.42 \\
\hline Sweet Star & 26.25 & 43.23 & 2.05 & 22.38 & 1492.04 \\
\hline F1 Somya & 25.31 & 43.9 & 1.97 & 18.71 & 1247.47 \\
\hline F1 Ajay & 30.43 & 45.57 & 1.55 & 14.14 & 942.71 \\
\hline Goody Ball-6 & 25.51 & 42.57 & 1.52 & 11.70 & 779.84 \\
\hline Zebra-9 & 25.83 & 45.02 & 1.74 & 16.73 & 1115.37 \\
\hline Emerald-180 & 27.23 & 44.16 & 1.51 & 11.81 & 786.99 \\
\hline Black Wonder & 21.32 & 39.95 & 1.34 & 6.84 & 455.63 \\
\hline Hemavathi & 26.14 & 45.68 & 1.49 & 11.22 & 747.6 \\
\hline Sugar Baby (Std. Check) & 24.87 & 42.75 & 1.61 & 13.16 & 877.55 \\
\hline CD & $\mathbf{3 . 3 8}$ & $\mathbf{2 . 3 5}$ & $\mathbf{0 . 1 5}$ & $\mathbf{2 . 7 2}$ & $\mathbf{1 8 1 . 3 0}$ \\
\hline
\end{tabular}


Table.3 Evaluation of watermelon hybrids for TSS and Organoleptic properties

\begin{tabular}{|l|c|c|}
\hline \multicolumn{1}{|c|}{ Hybrids } & $\begin{array}{c}\text { Overall acceptability } \\
\text { (Color \& appearance, } \\
\text { Texture, Flavor \& Taste) }\end{array}$ & $\begin{array}{c}\text { TSS } \\
\left(\text { Brix }^{\mathbf{0}}\right)\end{array}$ \\
\hline F1 Black king & 5.33 & 12.21 \\
\hline F1 Mithun & 5.44 & 13.24 \\
\hline F1 Sartaj-295 & 8.22 & 15.10 \\
\hline Sweet Star & 5.00 & 14.42 \\
\hline F1 Somya & 5.11 & 11.59 \\
\hline F1 Ajay & 5.33 & 12.44 \\
\hline Goody Ball-6 & 6.00 & 13.61 \\
\hline Zebra-9 & 5.78 & 11.11 \\
\hline Emerald-180 & 6.00 & 13.56 \\
\hline Black Wonder & 4.33 & 10.22 \\
\hline Hemavathi & 5.89 & 11.55 \\
\hline Sugar Baby (Std. Check) & 5.89 & 12.26 \\
\hline CD & $\mathbf{1 . 2 9}$ & $\mathbf{0 . 5 7}$ \\
\hline
\end{tabular}

Fig.1 Histogram depicting performance of watermelon hybrids on days to germination, days to first female flower appearance, no: of female and male flower per plant

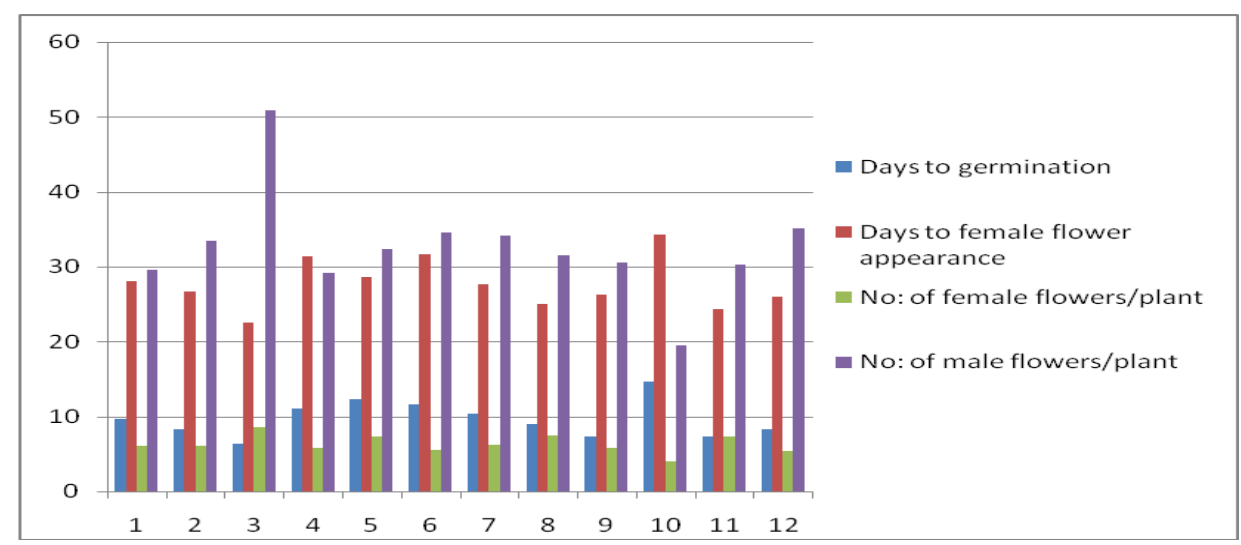

Fig.2 Histogram depicting yield of water melon hybrids yield per/ha

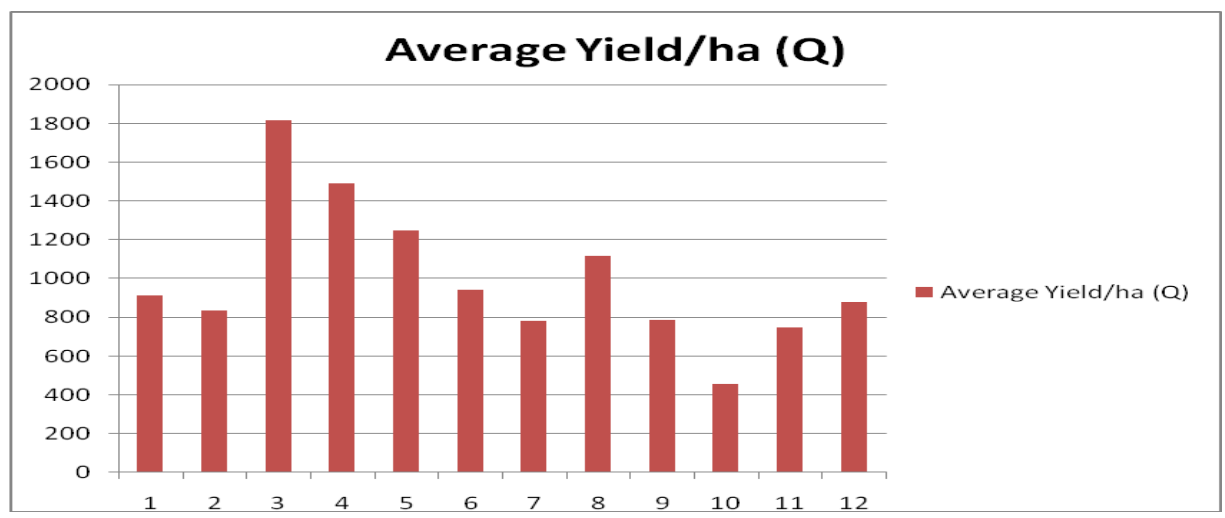


Fig.3 Histogram depicting of watermelon hybrids for TSS and Organoleptic properties

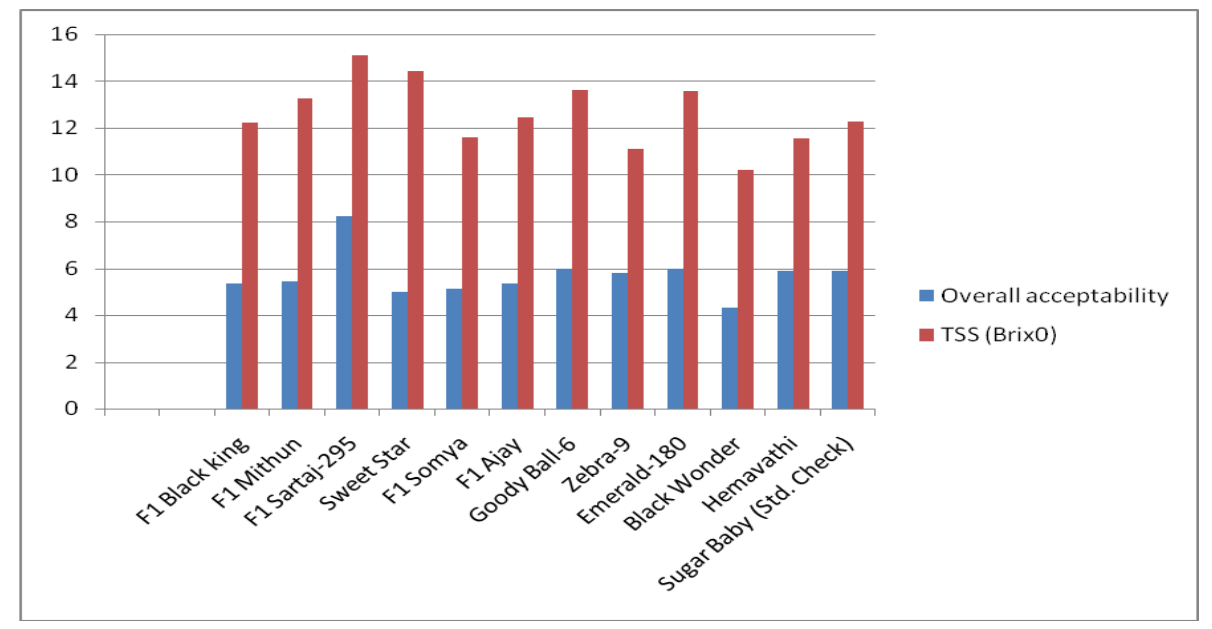

\section{Quality}

The watermelon fruit was evaluated for the sensory attributes of Colour, Appearance, Texture, Flavor, Taste and overall acceptability by a panel of 5 judges selected from Department of Horticulture through Organoleptic Test. 9 points Hedonic scale score was used for the purpose (Srilakshmi 2003). The highest score for color and appearance, texture, flavor and taste and overall acceptability score recorded in the watermelon $(8.00,8.67,8.00$ and 8.22) was recorded in hybrid F1 Sartaj-295 whereas the lowest score of (3.00, 4.67, 5.33 and 4.33) was found in hybrid Black Wonder. The highest TSS (Brix ${ }^{0}$ ) (15.10) was found in F1 Sartaj-295 followed by Sweet Star, and the lowest TSS (Brix $\left.{ }^{0}\right)(10.22)$ was observed in hybrid Black Wonder. The higher TSS value may be due to the inherent characteristics of the hybrid. Similar observations were made by More et al., (2015) in watermelon, Madhuri (2016) in watermelon (Fig. 3 and Table 3).

\section{Economics}

The maximum gross return (1089252 Rs/ha), net return (918090.4 Rs/ha), Benefit Cost ratio (6.36) was recorded for F1 Sartaj-295 and the minimum was recorded for Black wonder; gross return (273378 Rs/ha), net return (102216.4 Rs/ha), Benefit Cost ratio (1.60).

In conclusion the results obtained from the present study indicated that, out of the twelve watermelon hybrids studied, F1 Sartaj-295 was found to be the most promising in respect to growth, yield, and quality characters. And the hybrid Black wonder has given the poor performance under Prayagraj agro-climatic condition. In terms of Economics i.e., gross return, net return and Benefit Cost ratio, F1 Sartaj-295 was found to be the better option for small and marginal farmers for cultivation in Prayagraj agro-climatic condition.

\section{Acknowledgement}

Authors thank Dr. Vijay Bahadur, Associate Professor, Department of Horticulture, Naini Agricultural Institute, SHUATS, Prayagraj whose generous help, untiring guidance, supervision, suggestions and positive attitude during my work.

\section{References}

Athens F (1998), Commercial watermelon production. Extension service, 
University of Georgia, College of Agriculture.

Emmanuel Mremaa and Amon P. Maerereb (2018). Growth and yield performance of watermelon during dry and wet seasons under tropical conditions. International journal of vegetable science 2012; 4(13):461-471.

FAOSTAT (2006), Available at: http://www.faostat.fao.org.

Gichimu BM, Owuor BO, Mwai GN, Dida MM. (2009). Morphological characterization of some wild and cultivated watermelon (Citrullus sp.) accessions in Kenya. Journal of Agricultural and Biological Science. 2009; 4(2):10-18.

Jadhav, P. B.; Saravaidya, S. N.; Tekale, G. S.; Patel, D. J.; Patil, N. B.; Harad, N.B.; Dekhane, S. S.; (2013). Performance of different varieties in respect of plant growth, yield, and quality of watermelon (Citrullus Lanatus Thunbmansf).

Narine, R., Chandranauth, R., Chibi, S. and Homenauth, (2019) Evaluation of Five
Hybrid Watermelon Varieties for Cultivation and Performance in Coastal Guyana South America. Agricultural Sciences, 10, 538-545.

Okemah, L. U. 2Agbogidi, O.M. and Nwagu, O.K. (2011) Evaluation of four varieties of watermelon (Citrullus lanatus thumb) in Asaba agroecological environment. I.J.A.B.R., VOL. 1(1) 2011:126-130

Rai M, Kumar, S., Pandey S, Singh M, Singh, B (2004) Popular Varieties of Vegetable Crops in India. Indian Institute of Vegetable Research Publication, Varanasi, p. 1-93.

Venkatesan K., Malleswara B. Reddy, and N. Senthil (2016), Evaluation of Muskmelon (Cucumis melo L.) genotypes for growth, yield, and quality traits. Electronic Journal of Plant Breeding,

Vijayakumari, P., More, T. A. and Seshadri, V. S., (2005). Evaluation of gynoecious F1 hybrids for horticultural characters in cucumber. Veg. Sci., 18 (2): 167-176 (2005).

\section{How to cite this article:}

Liya Joy, Vijay Bahadur and Anita Kerketta. 2020. Performance of Different Hybrids of Watermelon (Citrullus lanatus) under Prayagraj Agro-climatic Condition. Int.J.Curr.Microbiol.App.Sci. 9(12): 50-57. doi: https://doi.org/10.20546/ijcmas.2020.912.008 